\title{
PENERIMAAN TUBEKTOMI SEBAGAI METODE KONTRASEPSI DI KABUPATEN PANGKEP
}

\author{
Nawang Fea Aurora ${ }^{1}$, Muh. Andi Multazam², Suharni A. Fachrin ${ }^{3}$ \\ (dr.nawang06@gmail.com) \\ 1,2,3Universitas Muslim Indonesia
}

\begin{abstract}
ABSTRAK
Program keluarga berencana mendukung upaya pengendalian pertumbuhan penduduk. Salah satu upaya program KB yaitu meningkatkan penggunakan metode kontrasepsi jangka panjang seperti kontrasepsi tubektomi. Tujuan penelitian ini adalah untuk memahami lebih mendalam mengenai penerimaan kontrasepsi tubektomi di Kabupaten Pangkep. Jenis penelitian ini adalah kualitatif dengan pendekatan fenomenologi untuk melakukan eksplorasi mengenai keputusan pemilihan tubektomi dengan teknik wawancara mendalam (In-depth interview) dan observasi selama penelitian berlangsung. Penelitian ini bersifat deskriptif seperti transkip wawancara, foto, rekaman suara dan lain-lain.Hasil penelitian ini menunjukkan bahwa pengetahuan akseptor tubektomi rendah. Motivasi, dukungan suami dan peran tenaga kesehatan sangat berperan Faktor penyulit menjadi salah satu penyebab dan faktor jumlah anak berpengaruh terhadap keputusan pemilihan metode tubektomi di Kabupaten Pangkep. Dapat disimpulkan penerimaan tubektomi di Kabupaten Pangkep sudah baik karena adanya peran yang besar dari tenaga kesehatan yaitu dokter kandungan dan bidan yang selalu berusaha untuk memotivasi pasien dan memberikan informasi kepada para akseptor. Juga dukungan suami yang juga ikut berperan besar dalam penerimaan tubektomi.
\end{abstract}

Kata Kunci : penerimaan, tubektomi, keluarga berencana

\begin{abstract}
The family planning program supports the efforts of population growth control. One of the efforts of the family planning program is to increase the use of long-term contraceptive methods such as tubectomy contraception. This research aimed to understand more deeply about tubectomy contraceptive acceptance in Pangkep Regency. The type of this research is qualitative with phenomenology approach to explore the decision of tubectomy selection by in-depth interview and observation during the research. This research is descriptive such as interview transcript, photo, sound recording and others. The result showed that the knowledge of tubectomy acceptors is low. Motivation, the support of husband and the role of health personnel is very important. The difficult factors become one of the causes and factors of the number of children influencing to the decision of tubectomy selection method in Pangkep Regency. It can be concluded that the tubectomy acceptance in Pangkep Regency is good because there is a big role of health personnel that is gynecologist and midwife always try to motivate the patients and give the information to the acceptors, and also husband support who also played a major role in tubectomy reception.
\end{abstract}

Keywords : acceptance, tubectomy, family planning

\section{A. PENDAHULUAN}

Masalah kependudukan di Indonesia sangat kompleks, baik dari segi kualitas, kuantitas, mobilitas/persebaran serta dari sisi data, informasi dan administrasi kependudukan. Estimasi Jumlah penduduk Indonesia tahun 2013 sebesar 248.422.956 jiwa dengan angka pertumbuhan penduduk yang masih tergolong tinggi yaitu sekitar 1,49\% per tahun). Hasil estimasi jumlah penduduk tahun 2015 sebesar 255.461.686 jiwa. Jika laju pertumbuhan tidak dikendalikan, diperkirakan jumlah penduduk di Indonesia tahun 2045 mencapai dua kali lipat dari jumlah sekarang, menjadi sekitar 450 juta jiwa.

Peraturan Pemerintah Republik Indonesia Nomor 87 Tahun 2014 tentang 
Perkembangan Kependudukan dan Pembangunan Keluarga, Keluarga Berencana, dan Sistem Informasi Keluarga menyebutkan bahwa program keluarga berencana $(\mathrm{KB})$ adalah upaya mengatur kelahiran anak, jarak dan usia ideal melahirkan, mengatur kehamilan, melalui promosi, perlindungan, dan bantuan sesuai dengan hak reproduksi untuk mewujudkan keluarga yang berkualitas.

Dalam Rencana Pembangunan Jangka Menengah (RPJMN) tahun 20092014, tertuang bahwa dalam rangka mempercepat pengendalian fertilitas melalui penggunaan kontrasepsi, program keluarga berencana nasional di Indonesia lebih diarahkan kepada pemakaian Metode Kontrasepsi Jangka Panjang (MKJP) adalah kontrasepsi yang dapat dipakai dalam jangka waktu lama, lebih dari dua tahun, efektif dan efisien untuk tujuan mencegah kehamilan atau mengakhiri kehamilan pada pasangan yang sudah tidak ingin menambah lagi.

Menurut Kemenkes RI tahun 2015 bahwa metode kontrasepsi yang paling banyak digunakan di Indonesia oleh akseptor KB aktif adalah suntikan $(48,98 \%)$ dan terbanyak ke dua adalah pil $(26,36 \%)$, implant (9,63\%), IUD (6,81\%), kondom $(5,47 \%)$. Sedangkan metode kontrasepsi yang sedikit dipilih oleh akseptor KB aktif adalah Metoda Operasi Wanita (MOW) $(1,64 \%)$ dan Operasi Pria (MOP), yakni sebanyak $0,16 \%$. Sedangkan pada peserta KB baru, suntikan adalah metode yang paling banyak digunakan yakni sebesar $47,78 \%$. Metode terbanyak ke dua adalah pil, sebesar $23,6 \%$, implant $(10,58 \%)$, IUD $(10,73 \%)$, kondom $(3,16 \%)$. metode operasi wanita (MOW) sebanyak 3,49\%, Metode Operasi Pria (MOP) sebesar 0,65\%. Persentase peserta KB baru terhadap pasangan usia subur di Indonesia pada tahun 2015 sebesar 13,46\%. Angka ini lebih rendah dibandingkan capaian tahun 2014 yang sebesar 16,51

Dari data Kemenkes RI 2015 persentase peserta KB baru di Sulawesi Selatan tahun 2015 sebesar 15,43\% dan KB aktif $70,70 \%$. Pada peserta KB baru, suntikan $(50,14 \%)$, pil, $(28,57 \%)$, implant $(10,38 \%)$, IUD $(3,43 \%)$, kondom $(5,7 \%)$. metode operasi wanita (MOW) sebanyak 1,78\%, Metode Operasi Pria (MOP) sebesar $0,09 \%$. Peserta KB aktif, suntikan $(47,19 \%)$, pil $(27,94 \%)$, implant $(12,67 \%)$, IUD $(4,87 \%)$, kondom $(5,2 \%)$. metode operasi wanita (MOW) sebanyak 1,97\%, Metode Operasi Pria (MOP) sebesar $0,19 \%)$.

Program MKJP yang sangat sedikit sekali dipilih yaitu MOW / tubektomi karena MOW / tubektomi merupakan kontrasepsi mantap / permanen yang berarti akseptor

yang sudah melakukan MOW / tubektomi berarti tidak dapat melahirkan kembali. Kontrasepsi permanen pada wanita disebut dengan tubektomi atau biasa disebut dengan Metode Operasi Wanita (MOW) adalah tindakan penutupan terhadap kedua saluran telur kanan dan kiri, yang menyebabkan sel telur tidak dapat melewati saluran tersebut, dengan demikian sel telur tidak dapat bertemu dengan sperma laki-laki sehingga tidak terjadi kehamilan.

Data dari BKKBN Pangkep 2014 persentase peserta KB baru di Kabupaten Pangkep tahun 2014 sebesar 93,67\% dan KB aktif $113,04 \%$. Pada peserta KB baru, suntikan sebanyak 5.096 akseptor $(56,95 \%)$ pil sebanyak 2.865 akseptor (32\%), implant sebanyak 290 akseptor $(3,24 \%)$, IUD sebanyak 31 akseptor $(0,34 \%)$, kondom sebanyak 544 akseptor (6\%). metode operasi wanita (MOW) sebanyak 121 akseptor (1,35\%), Metode Operasi Pria (MOP) sebanyak 0 akseptor (0\%). Peserta KB aktif, suntikan sebanyak 23.794 akseptor $(56,29 \%)$, pil sebanyak 13.000 akseptor $(30,52 \%)$, implant sebanyak 2.116 akseptor $(4,96 \%)$, IUD sebanyak 372 akseptor $(0,87 \%)$, kondom sebanyak 2.667 akseptor $(6,28 \%)$. metode operasi wanita (MOW) sebanyak 445 akseptor (1\%), Metode Operasi Pria (MOP) sebanyak akseptor (0\%)

Data dari BKKBN Pangkep 2015 persentase peserta KB baru di Kabupaten Pangkep tahun 2015 sebesar 86,39\% dan KB aktif $112,79 \%$. Pada peserta KB baru, suntikan sebanyak 3.656 akseptor $(60,87 \%)$ pil sebanyak 1.538 akseptor (25,6\%), implant sebanyak 193 akseptor $(3,21 \%)$, IUD sebanyak 131 akseptor (2,18\%), kondom sebanyak 286 akseptor $(4,76 \%)$. metode operasi wanita (MOW) sebanyak 200 akseptor (3,33\%), Metode Operasi Pria (MOP) sebanyak 2 akseptor $(0,03 \%)$. Peserta KB aktif, suntikan sebanyak 24.223 akseptor (57\%), pil sebanyak 13.106 akseptor (30\%), implant sebanyak 1.993 akseptor (4,6\%), IUD sebanyak 369 akseptor $(0,8 \%)$, kondom sebanyak 2.285 akseptor $(5,3 \%)$. metode operasi wanita Bina Generasi; Jurnal Kesehatan $\mid 22$ 
(MOW) sebanyak 502 akseptor (1,1\%), Metode Operasi Pria (MOP) sebanyak 14 akseptor (0,03\%) (BKKBN Pangkep, 2015).

Data dari BKKBN Pangkep 2016 persentase peserta KB baru di Kabupaten Pangkep tahun 2016 sebesar 61,92\% dan KB aktif $114,40 \%$. Pada peserta KB baru, suntikan sebanyak 3.567 akseptor $(60,6 \%)$ pil sebanyak 1.305 akseptor $(22,1 \%)$, implant sebanyak 401 akseptor $(6,81 \%)$, IUD sebanyak 332 akseptor $(5,63 \%)$, kondom sebanyak 88 akseptor $(1,49 \%)$. metode operasi wanita (MOW) sebanyak 190 akseptor (3,22\%), Metode Operasi Pria (MOP) sebanyak 4 akseptor (0,06\%). Peserta KB aktif, suntikan sebanyak 24.652 akseptor (58,8\%), pil sebanyak 12.585 akseptor (30\%), implant sebanyak 2.142 akseptor $(5,11 \%)$, IUD sebanyak 460 akseptor $(1,09 \%)$, kondom sebanyak 1.387 akseptor $(3,31 \%)$. metode operasi wanita (MOW) sebanyak 642 akseptor (1,53\%), Metode Operasi Pria (MOP) sebanyak 24 akseptor (0,05\%) (BKKBN Pangkep, 2016).

Jumlah peserta KB aktif kontrasepsi tubektomi di Kabupaten Pangkep meningkat dari tahun 2014 sebesar 445 akseptor, tahun 2015 sebesar 502 akseptor hingga tahun 2016 sebesar 642 akseptor. Jumlah peserta KB baru meningkat tajam dari tahun 2014 sebesar 121 akseptor ke tahun 2015 sebesar 200 akseptor dan sedikit menurun pada 2016 sebesar 190 akseptor.

Sehubungan dengan penggunaan metode kontrasesi tubektomi di Kabupaten Pangkep ada beberapa faktor yang turut berperan dalam pengambilan suatu keputusan seperti pengetahuan, jumlah anak, peran tenaga kesehatan hingga dukungan suami.

Penelitian ini bertujuan untuk Mendapatkan informasi mengenai penerimaan kontrasepsi di kabupaten Pangkep.

\section{METODE}

Jenis penelitian ini adalah kualitatif dengan pendekatan fenomenologi. Penelitian ini berusaha untuk mendapatkan informasi tentang penerimaan kontrasepsi tubektomi dan faktor-faktor yang mempengaruhi penerimaan kontrasepsi tubektomi melalui observasi, in-depth interview, dan dokumentasi selama proses penelitian di Kabupaten Pangkep
Penelitian ini mengguakan teknik sampling yaitu sampling purposive. Sampling purposive adalah teknik penentuan sampel dengan pertimbangan tertentu.

Adapun karakteritik penentuan informan dalam penelitian ini adalah sebagai berikut: Wanita Usia Subur (WUS) I Produktif, Berstatus Nikah, Akseptor tubektomi Bersedia menjadi informan. Jenis informan yang digunakan dalam penelitian ini yaitu informan kunci, informan biasa dan informan pendukung. Pengumpulan data diperoleh dari data primer yaitu observasi atau pengamatan dan wawancara sedangkan data sekunder diperoleh dari buku-buku atau bahan-bahan tertulis yang berhubungan dengan tubektomi dan data pasangan suami istri yang memilih kontrasepsi tubektomi di RSUD Pangkep dan data dari BKKBN Pangkep.

\section{HASIL \\ Pengetahuan}

Berdasarkan dari jenis-jenis pertanyaan yang diajukan untuk mengetahui tingkat pengetahuan informan, pertanyaan mengenai kontrasepsi tubektomi dari 15 informan hanya 4 informan yang bisa menjawab dengan rinci mengenai kontrasepsi tubektomi. Sementara untuk pertanyaan mengenai manfaat, efek samping, indikasi dan cara melakukan metode tubektomi sebagian besar informan yaitu 11 informan tidak bisa menjawab dengan rinci.

Dari seluruh informan mereka yakin jika sudah melakukan kontrasepsi tubektomi tidak bisa mempunyai anak kembali sehingga mereka mau melakukan kontrasepsi tubektomi.

\section{Paritas / jumlah anak}

Hampir semua informan yaitu 14 informan mempunyai jumlah anak tiga atau lebih dan hanya satu informan yang mempunyai jumlah anak dua. Tetapi informan yang memiliki jumlah anak dua mau Melakukan tubektomi karena mempunyai resiko penyakit pada kehamilan dan persalinan.

Sebagian informan yaitu 8 informan tidak mengetahui jika jumlah anak dapat mempengaruhi kesehatan. Mereka berpikir kalau jumlah anak yang banyak tidak ada masalah dengan kesehatan mereka. Hanya 7 informan yang mengetahui jika jumlah 
anak yang banyak dapat mempengaruhi kesehatan.

\section{Motivasi}

Sebagian informan yaitu 8 informan mengatakan bahwa motivasi untuk melakukan kontrasepsi tubektomi berasal dari diri sendiri. Motivasi tersebut juga karena para informan memiliki resiko penyakit pada kehamilan dan persalinan.

Informan lainnya yaitu 7 informan juga mengatakan bahwa motivasi untuk melakukan kontrasepsi tubektomi berasal dari luar yaitu dari tenaga kesehatan (dokter kandungan dan bidan) dan dari suami. Tenaga kesehatan (dokter kandungan dan bidan memotivasi informan untuk melakukan tubektomi karena informan memiliki resiko penyakit pada kehamilan dan persalinan.

Semua informan mengatakan bahwa mereka mendapat dukungan baik dari keluarga maupun suami. Keluarga dan suami setuju jika informan melakukan kontrasepsi tubektomi.

\section{Faktor penyulit / masalah kesehatan}

Semua informan mengatakan bahwa mereka memiliki resiko penyakit pada kehamilan dan persalinan. Karena hal tersebut maka para informan mau melakukan kontrasepsi tubektomi.

Sebagian besar informan yaitu 12 informan mengatakan mereka tidak mempunyai riwayat penyakit sebelumnya, tidak ada masalah dalam kehamilan dan persalinan. Semua persalinan normal. Hanya pada kehamilan yang sekarang para informan memiliki resiko penyakit pada kehamilan dan persalinan. Sedangkan 3 Informan lainnya memang memiliki riwayat penyakit sebelumnya dan mereka memang mau melakukan tubektomi karena sadar memiliki resiko penyakit pada kehamilan dan persalinan.

\section{Dukungan Suami}

Semua suami informan setuju jika istrinya melakukan kontrasepsi tubektomi. Karena mereka ingin agar tidak ada masalah pada kesehatan istrinya dan ingin agar istrinya terhindar dari resiko penyakit pada kehamilan dan persalinan.

Walau awalnya ada 3 suami informan yang tidak setuju istrinya melakukan kontrasepsi tubektomi tetapi akhirnya setuju karena melihat kondisi dan kesehatan istrinya.
Dukungan yang diberikan suami informan berupa menemani saat control kehamilan, menemani selama informan melakukan tubektomi.

\section{Peran tenaga kesehatan}

Tenaga kesehatan (dokter kandungan dan bidan) sangat berperan dalam memotivasi informan untuk mau melakukan kontrasepsi tubektomi. Terutama informan yang mempunyai resiko penyakit pada kehamilan dan persalinan.Tenaga kesehatan berperan dalam memberi informasi agar informan mengerti dan mau melakukan tubektomi sehingga informan terhindar dari resiko penyakit pada kehamilan dan persalinan.

\section{PEMBAHASAN}

\section{Penerimaan Tubektomi sebagai Metode Kontrasepsi di Kabupaten Pangkep berdasarkan dengan Pengetahuan}

Pengetahuan informan yang didapat dari hasil penelitian yaitu memiliki pengetahuan yang rendah karena pada umumnya informan belum memahami tentang kontrasepsi tubektomi. Para informan hanya mengetahui jika sudah melakukan tubektomi tidak bisa mempunyai anak lagi. Informan tidak bisa menjelaskan secara terperinci tentang kontrasepsi tubektomi. Pengetahuan informan sangat minim mengenai efek samping, indikasi, cara melakukan dan manfaat yang didapat dari kontrasepsi tubektomi.

Pengetahuan informan dari hasil penelitian juga dilandasi olen beberapa alasan seperti keputusan informan untuk melakukan tubektomi karena usia yang sudah tua yang juga dapat memiliki resiko terhadap efek samping kontrasepsi, keputusan informan yang tidak ingin mempunyai anak lagi, mempunyai faktor resiko penyakit pada kehamilan dan persalinan, juga dari informasi yang didapat oleh informan tentang metode tubektomi yang didapat dari lingkungan sekitar seperti keluarga, teman, tetangga, petugas kesehatan (dokter kandungan dan Bidan) dan juga dengan mencari informasi tentang kontrasepsi tubektomi dari internet.

Hal ini sesuai dengan pernyataan Notoatmodjo (2003) bahwa pengetahuan adalah merupakan hasil dari tahu, dan ini terjadi setelah orang melakukan penginderaan terhadap suatu obyek tertentu. Penginderaan terjadi melalui panca indera manusia, yakni indera penglihatan, pendengaran, penciuman, 
rasa dan raba. Sebagian besar pengetahuan manusia diperoleh dari mata dan telinga. Pengetahuan umumnya datang dari pengalaman juga dapat diperoleh dari informasi yang disampaikan oleh orang lain, dari buku, surat kabar atau media massa atau media elektronik.

Dari hasil penelitian ini juga didapat bahwa semua informan yakin bahwa jika mereka sudah melakukan tubektomi maka tidak bisa hamil kembali. Hal ini juga yang meningkatkan minat dan keinginan dari para informan terhadap metode tubektomi. Mereka mengetahui bahwa penggunaan metode tubektomi dapat membatasi kelahiran.

Hasil penelitian ini seakan mendukung pernyataan Ancok Djamaluddin (2014) yang mengatakan pengetahuan yang dipahami merupakan awal sehingga terciptanya keyakinan seseorang terhadap sesuatu dan akhirnya menjadi penentu akankah seseorang akan bersifat positif atau negative dan selanjutnya bisa membuat seseorang berniat dan melakukan atau bahkan menghindarinya.

Penelitian ini sejalan dengan penelitian Andi Hermawan dkk (2011) yang berjudul Faktor-Faktor yang Mempengaruhi Minat Wanita Usia Subur memilih kontrasepsi MOW di desa Butuh, Purwokerto. Dari hasil penelitian didapatkan bahwa tidak terdapat hubungan antara minat Wanita Usia Subur memilih kontrasepsi MOW dengan pengetahuan.

Berdasarkan hasil analisis dalam penelitian bahwa pengetahuan bukan salah satu variable yang berpengaruh terhadap penerimaan tubektomi. Karena walau pengetahuan yang rendah dari para informan, tetapi kontrasepsi tubektomi tetap diterima oleh informan. Para informan memang memiliki pengetahuan yang rendah, yaitu para informan hanya mengetahui bahwa tubektomi tidak bisa mempunyai anak lagi dan tidak mengetahui hal lainnya, tetapi hal itu sudah membuat informan yakin dan mau menggunakan kontrasepsi tubektomi.

\section{Penerimaan Tubektomi sebagai Metode Kontrasepsi di Kabupaten Pangkep berdasarkan Jumlah Anak atau Paritas}

Berdasarkan hasil penelitian didapatkan bahwa faktor jumlah anak pengguna tubektomi berpengaruh terhadap keputusan penggunaan kontrasepsi tubektomi, terlihat dari jawaban para informan bahwa hampir semua informan memilki jumlah anak tiga atau lebih.
Hal ini sejalan dengan pendapat Hartanto (2004) bahwa salah satu perencanaan kehamilan antara lain dengan mengikuti program keluarga berencana (KB). KB memberi pasangan pilihan tentang kapan sebaiknya mempunyai anak, berapa jumlahnya, jarak antar anak yang satu dengan yang lain dan kapan sebaiknya berhenti mempunyai anak. Sehingga dapat meningkatkan kesejahteraan ibu dan anak serta mewujudkan keluarga yang bahagia dan sejahtera.

Dari hasil penelitian didapatkan juga bahwa sebagian besar informan tidak mengetahui bahwa mempunyai banyak anak juga meningkatkan resiko penyakit pada kehamilan dan persalinan. Mereka menganggap

bahwa memiliki jumlah anak yang banyak tidak mempengaruhi kesehatan. Mereka merasa tidak ada masalah dalam kesehatan. Sebagian informan ada yang mengetahui bahwa banyak anak dapat mempengaruhi kesehatan, dapat meningkatkan resiko penyakit pada kehamilan dan persalinan.

Dari pernyataan Pinem, 2009 bahwa jumlah anak/ paritas juga dapat mempengaruhi kesehatan seseorang. Perempuan yang mempunyai jumlah anak lebih dari tiga dapat menyebabkan terjadinya gangguan kesehatan terutama pada saat kehamilan dan persalinan dengan resiko tinggi bagi ibu dan anak.

Hasil penelitian ini didukung oleh penelitian yang dilakukan oleh Rakhi Arya et all (2015) yang berjudul Profile of Post Partum Female Sterilization at Tertiary Care Government Hospital, Jaipur India yaitu untuk mengetahui faktor apa saja yang mempengaruhi dalam pemilihan sterilisasi wanita. Didapatkan hasil bahwa junlah anak/paritas berpengaruh dengan pemilihan sterilisasi wanita.

Berdasarkan hasil analisis dalam penelitian bahwa faktor jumlah anak menjadi salah satu variable yang berpengaruh terhadap penerimaan tubektomi, hal tersebut disebabkan bahwa memiliki jumlah anak yang banyak (jumlah anak tiga atau lebih) dapat mempengaruhi kesehatan ibu. karena memiliki jumlah anak yang banyak (jumlah anak tiga atau lebih) merupakan salah satu faktor resiko penyakit pada kehamilan dan persalinan.

\section{Penerimaan Tubektomi sebagai Metode Kontrasepsi di Kabupaten Pangkep berdasarkan dengan Motivasi}

Dari hasil penelitian didapatkan bahwa sebagian besar informan mengatakan mereka 
ingin melakukan tubektomi atas keinginannya sendiri, tetapi keinginan tersebut disebabkan karena adanya faktor resiko penyakit pada kehamilan dan persalinan yang dimiliki oleh para informan.

Pada hasil penelitian dari sebagian informan mengatakan mereka melakukan tubektomi karena dianjurkan oleh dokter kandungan di rumah sakit untuk melakukan tubektomi. Hal tersebut juga disebabkan adanya faktor resiko penyakit pada kehamilan dan persalinan yang dimiliki oleh para informan.

Hal ini didukung oleh pernyataan dari Hamalik (1992) yang mengatakan motivasi adalah suatu dorongan kehendak yang menyebabkan seseorang melakukan suatu perbuatan untuk mencapai tujuan tertentu.

Sifat motivasi juga ada dua menurut Dimyati dan Mudjiono (2002) yaitu intrinsic dan ekstrinsik. Motivasi intrinsic adalah yang berasal dari diri sendiri tanpa ada pengaruh dari luar. Motivasi ektrinsik adalah dorongan terhadap perilaku seseorang yang mendapat pengaruh atau rangsangan dari luar.

Dari hasil penelitian didapatkan bahwa motivasi intrinsic yaitu yang berasal dari diri informan sendiri dikarenakan kondisi fisik informan dan ada faktor resiko penyakit kehamilan dan persalinan. Sedangkan faktor ektrinsik yaitu yang berasal dari luar diri yaitu dari tenaga kesehatan (bidan dan dokter kandungan), keluarga terutama suami. Dukungan keluarga dan suami juga merupakan motivasi yang kuat untuk para informan. Karena persetujuan dari keluarga dan suami membuat mereka mau melakukan tubektomi. Hal itu sangat mempengaruhi pemilihan informan untuk melakukan tubektomi.

Hal ini sejalan dengan hasil penelitian dari Dwiana (2014) yang berjudul Beberapa Faktor yang Berhubungan dengan Pemilihan Kontrasepsi Metode Operatif Wanita (MOW) pada Akseptor Keluarga Berencana (KB) di desa Bejalen Kecamatan Ambarawa Kabupaten Semarang bahwa terdapat hubungan motivasi dengan pemakaian kontrasepsi MOW (tubektomi).

Dari semua penjelasan di atas, motivasi merupakan suatu faktor yang sangat mempengaruhi informan dalam penerimaan tubektomi, motivasi sangat diperlukan untuk informan dalam mengambil keputusan melakukan tubektomi. Motivasi yang didapat berasal dari motivasi intrinsic yaitu dari diri sendiri dan faktor ektrinsik yang berasal dari keluarga, suami dan tenaga kesehatan (dokter kandungan dan bidan). Motivasi yang baik dapat meningkatkan keputusan akseptor untuk menggunakan kontrasepsi tubektomi. Sedangkan motivasi yang kurang dapat membuat akseptor ragu dalam memilih menggunakan kontrasepsi tubektomi.

\section{Penerimaan Tubektomi sebagai Metode Kontrasepsi di Kabupaten Pangkep berdasarkan dengan Faktor Penyulit atau Masalah Kesehatan}

Dari hasil penelitian didapatkan bahwa keseluruhan dari informan mempunyai faktor resiko penyakit akibat kehamilan dan persalinan. Faktor resiko tersebut seperti jumlah anak yang dimiliki informan. Informan mengatakan bahwa hampir semua yang ingin melakukan tubektomi memiliki jumlah anak yang banyak (jumlah anak tiga atau lebih). Para informan juga kebanyakan memiliki usia yang sudah tua ( $\geq 35$ tahun) pada kehamilan yang sekarang, Usia yang sudah tua juga merupakan salah satu faktor resiko penyakit pada kehamilan dan persalinan dan juga dapat memiliki resiko terhadap efek samping kontrasepsi. Walaupun sebagian besar informan mengatakan bahwa sebelumnya tidak mempunyai masalah dalam kehamilan dan persalinannya tetapi pada kehamilan yang sekarang mempunyai resiko penyakit pada kehamilan dan persalinan. Dan jika tidak dihindari dan masih berlanjut dapat menjadi masalah yang serius bahkan kematian. Sehingga hal-hal tersebut yang membuat para informan memilih untuk melakukan kontrasepsi tubektomi.

Berdasarkan pernyataan Notoatmodjo (2003) bahwa masalah kesehatan dalam arti umum adalah masalah yang terjadi dalam diri seseorang, masalah yang terjadi itu bisa berupa masalah fisik, masalah mental dan masalah social. Yakni kematian, penyakit, kecacatan, ketidaknyamanan, ketidak puasan dan kemelaratan

Didapatkan juga dari hasil penelitian bahwa semua informan yakin jika mereka melakukan tubektomi maka mereka tidak mempunyai anak kembali dan mereka terhindar dari faktor resiko penyakit pada kehamilan dan persalinan sehingga tidak terjadi masalah dalam kesehatan mereka. Hal tersebut juga meningkatkan para informan untuk memilih melakukan kontrasepsi tubektomi .

Sesuai dengan pernyataan dari Manuaba (1992) bahwa angka efektifitas tubektomi 
hampir $100 \%$ sehingga kehamilan tidak dapat terjadi dan tubektomi merupakan $\mathrm{KB}$ yang permanen yang artinya tidak dapat dikembalikan jika ingin mempunyai anak kembali.

Hasil penelitian ini didukung oleh penelitian yang dilakukan oleh Rakhi Arya et all (2015) yang berjudul Profile of Post Partum Female Sterilization at Tertiary Care Government Hospital, Jaipur India yaitu untuk mengetahui faktor apa saja yang mempengaruhi dalam pemilihan sterilisasi wanita. Didapatkan hasil bahwa jenis penyakit berpengaruh dengan pemilihan sterilisasi wanita.

Dari semua penjelasan di atas, masalah kesehatan merupakan suatu faktor yang mempengaruhi dalam penerimaan tubektomi, Karena calon akseptor yang mempunyai masalah kesehatan atau mempunyai resiko penyakit pada kehamilan dan persalinan merupakan indikasi untuk dilakukan tubektomi agar tidak terjadi masalah pada dirinya dan calon anak. Karena jika tidak dilakukan maka ibu yang hamil dan calon anak bisa mendapatkan masalah kesehatan yang serius bahkan kematian.

\section{Penerimaan Tubektomi sebagai Metode Kontrasepsi di Kabupaten Pangkep berdasarkan dengan dukungan suami}

Dari hasil penelitian didapatkan jawaban dari para informan bahwa suami memberikan dukungan dengan menyutujui jika mereka melakukan tubektomi. Walaupun awalnya ada beberapa suami yang tidak setuju untuk dilakukan tubektomi. Tetapi karena melihat kondisi dan kesehatan

istrinya dan juga mendapat penjelasan dari dokter kandungan dan bidan tentang kontrasepsi tubektomi dan tentang faktor resiko penyakit pada kehamilan dan persalinan yang dimiliki oleh informan dan bahaya yang didapat jika tidak menghindari faktor resiko penyakit pada kehamilan dan persalinan maka para suami akhirnya mengerti dan setuju melakukan tubektomi.

Dari hasil penelitian didapatkan bahwa dukungan suami sangat dibutuhkan terhadap istri dalam memilih dan memutuskan untuk melakukan tubektomi. Karena persetujuan suami sangat dibutuhkan karena pada saat hendak mau melakukan operasi untuk tubektomi diperlukan persetujuan tindakan dari suami.

Sesuai dengan pernyataan dari Prasetyawati (2011) yaitu dukungan suami adalah dorongan yang diberikan oleh suami berupa dukungan moril dan materiil dalam hal mewujudkan suatu rencana yang dalam hal ini adalah pemilihan kontrasepsi. Dukungan suami membuat keluarga (istri) mampu melaksanakan fungsinya, karena anggota keluarga memang seharusnya saling memberikan dukungan dan saling memperhatikan keadaan dan kebutuhan kesehatan.

Hal ini juga sejalan dengan hasil penelitian dari Herlinawati (2012) yang berjudul Faktor-faktor yang Berhubungan dengan Pemakaian Kontrasepsi Tubektomi pada Wanita Pasangan Usia Subur di RSUD Dr. Pirngadi Medan bahwa terdapat hubungan dukungan suami dengan pemakaian kontrasepsi tubektomi.

Berdasarkan hasil analis dalam penelitian ini didapatkan bahwa suami akseptor mendukung keputusan penggunaan metode tubektomi.

Dukungan suami menjadi salah satu variable yang berpengaruh terhadap penerimaan tubektomi. Dukungan suami sangat dibutuhkan oleh seorang istri untuk merencanakan sesuatu hal dan mengambil keputusan. Bila suami tidak mengijinkan atau tidak mendukung, maka para istri akan cenderung mengikuti dan akhirnya tidak memilih menggunakan kontrasepsi tubektomi. Dukungan suami juga merupakan motivasi eksternal bagi istri. Motivasi dari suami sangat dibutuhkan oleh seorang istri. Suami yang selalu memberikan dukungan kepada istrinya membuat yakin seorang istri dalam mengambil sebuah keputusan. Seperti juga keyakinan seorang istri dalam memilih melakukan tubektomi.

\section{Penerimaan Tubektomi sebagai Metode Kontrasepsi di Kabupaten Pangkep berdasarkan Peran Tenaga Kesehatan}

Berdasarkan hasil penelitian sebagian besar informan mengatakan mereka melakukan tubektomi karena dianjurkan oleh dokter kandungan di rumah sakit untuk melakukan tubektomi. Hal tersebut juga disebabkan adanya faktor resiko penyakit pada kehamilan dan persalinan yang dimiliki oleh para informan.

Dan juga para informan mengetahui tentang metode tubektomi karena diberikan informasi dan penjelasan oleh tenaga kesehatan baik dokter kandungan atau bidan di 
rumah sakit. Dari pernyataan informan bahwa bidan di puskesmas juga ada yang menjelaskan tentang metode tubektomi. Tenaga kesehatan berusaha untuk menjelaskan agar para informan mengerti dan mau melakukan tubektomi. Hal tersebut menjadi pendukung bagi informan untuk mau melakukan tubektomi. Tenaga kesehatan juga berperan penting dalam memberikan motivasi kepada informan untuk mau menggunakan kontrasepsi tubektomi. Tenaga kesehatan berusaha untuk memberikan motivasi secara terus menerus kepada para informan. Motivasi dari tenaga kesehatan merupakan motivasi eksternal yang berasal dari luar diri para informan.

Berdasarkan UU No 36 tahun 2014 peran tenaga kesehatan atau fungsi tenaga kesehatan antara lain sebagai tenaga teknis yang juga memberikan pelayanan kepada masyarakat. Melaksanakan program yang telah dibuat oleh departemen kesehatan termasuk dalam penyuluhan kesehatan pada umumnya.

Tenaga kesehatan sangat berperan dalam memberikan informasi-informasi yang terkait dengan kesehatan dan juga memberikan pelayanan yang baik kepada masyarakat. Tenaga kesehatan terutama bidan harus berusaha untuk memberikan informasi tentang jenis-jenis kontrasepsi agar masyarakat khususnya ibu tidak bingung mengenai pemakaian KB setelah persalinan. Menjelaskan semua hal tentang jenis kontrasepsi agar masyarakat atau calon akseptor mengerti dan mau menggunakan kontrasepsi. Masih banyak perempuan mengalami kesulitan didalam menentukan pilihan jenis kontrasepsi. Hal ini tidak hanya karena keterbatasan metode yang tersedia, tetapi juga oleh ketidaktahuan mereka tentang persyaratan dan keamanan metode kontrasepsi tersebut. Pemberian informasi dapat dengan penyuluhan kepada masyarakat atau secara individual. Memberikan informasi tersebut juga dapat dibantu dengan poster atau pamflet tentang alat kontrasepsi.

Hal ini sejalan dengan penelitian oleh Laras Tsnay (2015) yang mengatakan bahwa terdapat pengaruh pemberiam informasi dan cara komunikasi serta edukasi yang baik tentang $\mathrm{Kb}$ pada wanita usia subur terhadap pemilihan tubektomi.

Berdasarkan hasil analis dalam penelitian ini didapatkan bahwa tenaga kesehatan sangat berperan dalam mendukung calon akseptor untuk melakukan tubektomi. Peran tenaga kesehatan menjadi salah satu variable yang berpengaruh terhadap penerimaan tubektomi. Tenaga kesehatan berperan dalam memberikan informasi dan penjelasan tentang kontrasepsi tubektomi kepada calon akseptor tubektomi dan juga memberikan motivasi agar calon akseptor tubektomi mengerti dan mau melakukan tubektomi. Tenaga kesehatan juga berperan dalam memberikan pelayanan kesehatan yang baik kepada calon akseptortubektomi. Hal itu semua dapat meningkatkan penggunaan kontrasepsi tubektomi.

\section{E. KESIMPULAN DAN SARAN Kesimpulan}

Pengetahuan yang dimiliki oleh para informan rendah. Mereka tidak dapat menjelaskan secara terperinci mengenai kontrasepsi tubektomi. Informan mengetahui informasi tentang kontrasepsi tubektomi dari lingkungan sekitar (keluarga, tetangga, teman, dan petugas kesehatan (dokter kandungan, bidan) dan mencari dari internet.

Jumlah anak dari hampir seluruh informan ada tiga atau lebih. Mempunyai banyak anak juga dapat mempengaruhi kesehatan dan meningkatkan resiko penyakit pada kehamilan dan persalinan. Informasi tersebut didapatkan dari petugas kesehatan (dokter kandungan dan bidan) juga mencari informasi di internet.

Motivasi informan ada yang berasal dari diri sendiri dan dari luar seperti dari suami, keluarga dan juga petugas kesehatan yaitu dokter kandungan dan bidan. Motivasi mempengaruhi keputusan menggunakan kontrasepsi tubektomi.

Keseluruhan informan mempunyai faktor resiko penyakit akibat kehamilan dan persalinan seperti usia tua, jumlah anak dan riwayat penyakit sebelumnya atau masalah kesehatan pada kehamilan dan persalinan yang sekarang sehingga dianjurkan untuk melakukan tubektomi oleh tenaga kesehatan yaitu dokter kandungan atau bidan agar terhindar dari faktor resiko penyakit pada kehamilan dan persalinan.

Didapatkan bahwa keseluruhan suami informan setuju jika istrinya melakukan tubektomi. Dukungan suami sangat dibutuhkan oleh seorang istri untuk merencanakan sesuatu hal dan mengambil suatu keputusan. Dukungan suami juga merupakan sebuah motivasi eksternal bagi para informan. 
Tenaga kesehatan yaitu dokter kandungan dan bidan sangat berperan, tenaga kesehatan memberikan informasi dan motivasi agar informan mengerti dan mau melakukan tubektomi. Hal ini sangat mendukung informan untuk mau melakukan tubektomi. Juga merupakan sebuah motivasi eksternal yang berasal dari luar diri sendiri.

\section{Saran}

Untuk pasangan suami istri agar lebih berusaha menambah informasi tentang metode tubektomi. Dengan cara mendapat informasi dari tenaga kesehatan (dokter kandungan dan bidan) dan juga mencari informasi dari internet. Informasi juga dapat

didapat dari poster atau brosur tentang tubektomi.

Untuk pasangan suami istri agar lebih dapat membatasi jumlah kelahiran anak dengan program KB. Salah satunya dengan menggunakan tubektomi. Karena mempunyai banyak anak dapat mempengaruhi kesehatan terutama untuk istri.

Untuk lebih dapat memberikan motivasi kepada akseptor baik dari keluarga terutama suami maupun tenaga kesehatan yaitu dokterkandungan dan bidan agar mau untuk mengikuti program KB yang salah satunya yaitu tubektomi. Karena motivasi sangat diperlukan agar para akseptor mau melakukan tubektomi.

Untuk pasangan suami istri terutama sang istri agar menambah informasi tentang penyakit-penyakit pada kehamilan dan persalinan dan juga faktor resiko. Agar mengerti dan dapat menghindari resiko-resiko yang ada pada penyakit akibat kehamilan dan persalinan.

Untuk suami agar selalu memberikan dukungan yang terbaik untuk para istri. Dukungan dari suami sangat diperlukan oleh istri untuk mengambil keputusan. Begitupula dalam mengambil keputusan untuk melakukan tubektomi. Dukungan yang baik dari suami untuk menjaga kesehatan istri dapat membuat istri terhindar dari faktor resiko pada kehamilan dan persalinan.

Tenaga kesehatan khususnya dokter kandungan dan bidan untuk lebih berusaha dalam memberikan informasi tentang penyakit pada kehamilan dan persalinan. Dan juga tentang jenis-jenis kontrasepsi terutama metode tubektomi.
Agar masyarakat mengerti tentang penyakit pada kehamilan dan persalinan dan juga mengerti tentang jenis-jenis kontrasepsi terutama tubektomi. Demi meningkatkan pengetahuan masyarakat tentang metode tubektomi dapat dengan cara memberikan informasi-informasi melalui media massa seperti menggunakan brosur atau buletin kesehatan tentang KB.

\section{DAFTAR PUSTAKA}

Arifah, Nur, 2013. Panduan Mudah Menyusun Skripsi - Tesis Distasi. Jakarta : Araska

Arya, Rakhi et all (2015). Profile of Post Partum Female Sterilization at Tertiary Care Government Hospital, Jaipur. International Multispecialy Journal of Health.

Badan Penelitian dan Pengembangan Kesehatan. (2010). Riset Kesehatan Dasar (Riskesdas 2010) Kementerian Kesehatan Republik Indonesia. Jakarta

BKKBN, 2015. Analisis Data Kependudukan dan KB www.bkkbn.go.id diakses tanggal pada 25 Februari 2017

BKKBN, 2010. Analisis Data Kependudukan dan KB www.bkkbn.go.id diakses tanggal pada 18 Februari 2017

BPS, 2010. Hasil Sensus Penduduk Tahun 2010. Jakarta. Badan Pusat Statistik RI.

Connigham, G.G, Mac Donald PC, Gant NF, 1991. Obstetri Williams. Jakarta : EGC

Derek, Llewellyn, 2001. Dasar-dasar Obstetri dan Ginekologi Edisi 6. Jakarta : EGC

Desi, Willy (2012). Karakteristik PUS yang Menggunakan Kontrasepsi MOW di Puskesmas Pesanggrahan Kecamatan Kutorejo Kabupaten Mojokerto.

Fakultas Kedokteran UI, 2001. Kapita Selekta Kedokteran Jilid 1. Jakarta : Media Aesculapius.

Fitra, dll (2012). Faktor-Faktor yang Berhubungan dengan Pemilihan Metode Kontrasepsi Tubektomi pada Pasangan Usia Subur. Jurnal Mahasiswa dan Peneliti Kesehatan 
Hacker, 2000. Esensial Obstetri dan Ginekologi Edisi 2. Jakarta : Hipocrates

Herlinawati, dll (2012). Faktor-FAktor yang Berhubungan Dengan Pemakaian Kontrasepsi Tubektomi Pada Wanita Pasangan Usia Subur di RSUD DR. Piringadi Medan.

KEMENKES RI, 2015. Profil Kesehatan Indonesia tahun 2015. www.depkes.go.id diakses tanggal 2 Maret 2017.

Khedkar, Devidas et al (2013). Behavioural and Fertility Factors Associated with Acceptance ot Non Acceptance of Tubectomy. National Journal of Community Medicine

Lakshmi, Getta et all (2015). A Study on Factors Influencing the choice of Permanent Method of Family Planning. Journal of Dental and Medical Science

Laras dll (2015). Analisis Faktor yang Berhubungan dengan Pemilihan Metode Kontrasepsi Jangka Panjang (MKJP) pada Akseptor $K B$ Wanita di Kecamatan Banyubiru, Kabupaten Semarang. Unnes Journal of Public Health

Manuaba, IBG, 2001. Ilmu Kebidanan, Penyakit, Kandungan dan Keluarga Berencana untuk Pendidikan Bidan. Jakarta : EGC

Manuaba, IBG, 1992. Operasi Kebidanan Kandungan dan Keluarga Berencana untuk Dokter Umum. Jakarta : EGC

Manuaba, IBG, Chandranita, I.A, 2001. Pengantar Kuliah Obstertri,Jakarta: EGC 